\title{
Muhsin Ertuğrul: Türk Sinemasının Kurucusu mu Yoksa Günah Keçisi mi?
}

\author{
SEÇKIN SEVIM* \\ sevims@bilkent.edu.tr
}

\begin{abstract}
Fakir varlığımızla yokluğa ilan-ı harp ettik, mücadele açtık. Artist yoktu, yaptık. Kadın yoktu, bulduk. Laboratuvar yoktu, kurduk. Makine yoktu, aldik. Senaryo yoktu, yazdik. Ama fena artist, ama çirkin kadın, ama iptidai laboratuvar, ama ucuz makina, ama fakir senaryo. Böylece filme başladık.
\end{abstract}

Muhsin Ertuğrul ${ }^{1}$

Özet: Muhsin Ertuğrul (1892-1979), Cumhuriyet'in ilk yıllarında çektiği filmlerle Türk sinemasının genetik kodlarını oluşturmuştur. Ertuğrul hakkındaki literatürde daha çok Nijat Özön’ün yazdıkları egemendir. Özön’ün eleştirilerinden yola çıkanlar, Ertuğrul’u Türk sinemasındaki olumsuzlukların sorumlusu olarak görmüşlerdir. Alim Şerif Onaran’n çalışmaları, Muhsin Ertuğrul hakkındaki önyargılı değerlendirmelerin etkisini bir ölçüde azaltmıştır. Ne var ki yokluklar içinde mücadele etmenin ve öncü olmanın zorlukları, Ertuğrul'un bir günah keçisi olarak görülmesini engelleyememiştir. Birçok sinema tarihçisinin de ifade ettiği gibi, Muhsin Ertuğrul'un tiyatroculuğu sinemacılı̆̆ına ă̆ır basmaktadır. Ertuğrul, ancak birkaç filminde vasatın üzerine çıkabilmiştir. Onun sinema mirası birçok açıdan eleştirilebilirse de Türkiye'de sinemanın varolabilmesi için harcadiğı çaba göz ardı edilemez. Teknolojiye en çok bağlı sanat dalı olan sinemayı yokluklar içinde var edebilmiş olması Muhsin Ertuğrul'u Türk sinema tarihi içinde ayrıcalıkl bir yere oturtur. Muhsin Ertuğrul'un filmleri, Kemalist modernleşme projesinin sinemadaki yansıması olarak izlenebilir. Ertuğrul, Cumhuriyet devrimlerinin hayata geçirilmesi için özveriyle mücadele etmiş bir kültür adamıdır. Türk kadınını ilk kez beyaz perdeye çıkarmakla kalmamış; tüm hayatı boyunca Cumhuriyet'in ideallerinin sanat alanındaki temsilcisi olmuştur. Bu amaçla eğitmenlik, yönetmenlik, eleştirmenlik, oyunculuk ve çevirmenlik gibi birçok misyonu aynı anda yüklenmek zorunda kalmıştır. Salgın hastalıklarla boğuşmak ve nüfusunu en azından ilkokul düzeyinde eğitmek gibi öncelikleri olan bir ülkede tiyatro ve sinema sanatının temellerini atmıştır. Nitekim bu çalışmanın amacı, Muhsin Ertuğrul'un Türk sinemasındaki kurucu rolünü ortaya koymaktır.

Anahtar kelimeler: Türk sinemasl, Muhsin Ertuğrul, Cumhuriyet, Kurucu rol.

\footnotetext{
* Öğr. Gör., Marmara Üniversitesi, Güzel Sanatlar Fakültesi, Film Tasarımı Bölümü.

1 Oğuz Makal, "Muhsin Ertuğrul Sineması Üzerine Bir Değerlendirme”, Ölümünün 5. Yılında Muhsin Ertuğrul Semineri Bildirileri, (İzmir: Ege Üniversitesi Atatürk Kültür Merkezi, 1984), 2.
} 


\section{Giriş}

Osmanlı İmparatorluğu'nun son dönemleri; Merkez Ordu Sinema Dairesi, Müdafaa-i Milliye Cemiyeti ve Malûl Gaziler Cemiyeti çatısı altında faaliyet gösteren Fuat Uzkınay (1888-1956), Sigmund Weinberg (1868-1954), Sedat Simavi (1896-1953) ve Ahmet Fehim Efendi (1856-1930) gibi isimlerin birtakım c1lız sinemacılık faaliyetlerine sahne olmuştur. Ne var ki bu çalışmalar, yeni kurulan Cumhuriyet'e canlı bir sinema ortamı sağlayamamıştır. Muhsin Ertuğrul (1892-1979), geç sanayileşmiş bir üçüncü dünya ülkesi olan Türkiye'de oyuncuların, teknik araç gereçlerin, senaristlerin, platoların ve hemen hemen hiçbir altyapının olmadığı son derece ilkel koşullarda sinema çalışmalarına başlamıştır.

Bu yazıda Türk sinemasında bir tür kurucu rolü üstlendiği hâlde özellikle Nijat Özön'ün eleştirileri nedeniyle Türk sinemasının en büyük günah keçilerinden biri hâline getirilmiş Muhsin Ertuğrul'un bir kültür ve sanat adamı olarak Cumhuriyet tarihinde üstlendiği misyona dikkat çekilecek ve onun sineması hakkındaki yargılar gözden geçirilecektir. Bu yazı, bir iade-i itibar yazısı değil, bütün olumsuz koşullara rağmen Türkiye'de sinemayı var eden bir kültür adamını yeniden değerlendirme çabası olarak okunmalıdır.

\section{Genç Bir Aktörün Bir İdealist Olarak Portresi}

II. Meşrutiyet'in ilanı (1908), sanat ve yayıncılık alanında müthiş bir hareketliliğe yol açar. Çocukluk yıllarından beri oyunculuk hayalleri kuran Muhsin Ertuğrul, sanat hayatına bu dönemde atılır. Canlandırdığı ilk rol, Burhanettin Kumpanyası'nın 2 Ağustos 1908'de Erenköy'de sahnelediği Sherlock Holmes oyunundaki Uşak Bob rolüdür. ${ }^{2} 1909$ yılından itibaren profesyonel olarak oyunculuk yapmaya başlar. Vahram Papazyan'ın tavsiyesiyle 1911 yılında Parise giden Ertuğrul, modern Batı tiyatrosunu menbainda gözlemleme imkânı bulur. ${ }^{3} 1912$ yılında İstanbul'a gelir ve Hamlet'i ilk kez sahneye koyan kişi olur. ${ }^{4}$ Ertuğrul, 1913 yılının Aralık ayında Paris'e döner. ${ }^{5}$ Tiyatro çalışmalarının yanı sıra sinema çalışmalarını da sürdürür. I. Dünya Savaşı öncesinde Avrupa’nın en gelişmiş sinema sektörlerinden birine sahip olan Fransa'da bir süre figüranlık yapar. Muhsin Ertuğrul, 1914 yılında yeniden İstanbul'a döner. Türk tiyatro tarihinde bir dönüm noktası olan Darülbedayi’nin kuruluş çalışmalarına katılır. Yıllar sonra bu çalışmalardan duyduğu sevinci İnsan ve Tiyatro Üzerine "Gördüklerim" adlı kitabında şu sözlerle dile getirir: "Nihayet Darülbedayi (Konservatuvar) kuruldu, genç tiyatrocular sığınacak bir sanat yuvasına kavuştular. Sabah karanlıkta yeni binaya geliyor, akşamları geç vakit çıkarken ayağımız geri geri gidiyordu."6

2 Nijat Özön, Türk Sinema Tarihi: Dünden Bugüne 1896-1960, (İstanbul: Artist Reklam Ortaklığı Yayınları, 1962), 61.

3 Efdal Sevinçli, "Muhsin Ertuğrul’un Tiyatro ve Sinema Yazıları", Ölümünün 5. Yllında Muhsin Ertuğrul Semineri Bildirileri, (İzmir: Ege Üniversitesi Atatürk Kültür Merkezi, 1984), 2.

4 Sevinçli, "Muhsin Ertuğrul'un", 2.

5 Sevinçli, "Muhsin Ertuğrul'un", 2.

6 Muhsin Ertuğrul, İnsan ve Tiyatro Üzerine “Gördüklerim”, (İstanbul: Yankı Yayınları, 1975), 74. 
Muhsin Ertuğrul, 1916 yılında ilk kez Almanya’ya gider; gündüzleri sinema stüdyolarında, geceleri de tiyatroda çalışır. ${ }^{7}$ Sinemadaki ilk rolüne Gecede Işılk (1916) filmiyle çıkar. ${ }^{8}$ Kısa sürede Berlin'deki sinema hayatının içine giren Ertuğrul, hem tiyatroda hem de sinemada önemli yönetmen ve oyuncularla tanışır. ${ }^{9}$ Almanya'da, İstanbul adıyla bir film şirketi kurar. ${ }^{10}$ Burcu Yasemin Şeyben'in de ifade ettiği gibi bugün için bile yabancı bir ülkede yönetmen olarak kabul görmek maharet ve cesaret gerektiren girişimlerdir:

O zamanlar sinemanın beşiği sayılan ülkelerden biri olan Almanya'da, bir film şirketinde kadrolu yönetmen olarak iş bulabilen Ertuğrul'un bu başarısı, günümüzde dahi birçok sinemacının erişmek hayalleri kurduğu dikkate değer bir hedeftir. ${ }^{11}$

Almanya'da ciddi bir yönetmenlik tecrübesi yaşayan Muhsin Ertuğrul, 1920'de dört tane uzun metrajlı film çeker: Samson, Kara Lale Bayramı, Şeytana Tapanlar, Ölüm Kervanı. ${ }^{12}$ Ertuğrul, Şeytana Tapanlar filminin çekimleri sırasında Cezmi Ar'la tanışır. ${ }^{13}$ Aslında oyunculuk yapmak isteyen Cezmi Ar'1 teknik elemana ihtiyacı olduğunu söyleyerek kameramanlığa yönlendiren Ertuğrul olur. ${ }^{14}$ Türk sineması bu sayede ilk görüntü ustasını kazanır. ${ }^{15}$

Muhsin Ertuğrul'un Almanya'da yaptığı film çalışmaları sinema çevrelerinin ilgi odağındadır. Özellikle senaristliğini, yönetmenliğini ve başrol oyunculuğunu üstlendiği Samson filminde gösterdiği çaba Berlin'de tartışma konusu olur. ${ }^{16}$ Ertuğrul, bu dönemde sinema eleştirisi alanındaki bilinen ilk ciddi eleştiri yazılarını da kaleme alır. Bu yazılarda, imparatorluğun son yıllarında İstanbul'da yürütülen cılız sinemacılık faaliyetlerini izlediği ve sinema yapmanın imkânlarını kolladığg görülmektedir. Ertuğrul, bu konudaki görüşlerini "Müdafaa-i Milliye Cemiyeti Riyaset-i Muhteremesine" başlıklı bir açık mektupta dile getirir:

İstanbul'da bugünkü şerait altında sinema şeridi yapmak kabil değildir. Sinema şeritleri yapmak isteyen müessese evvelâ iyi bir sinema operatörü [...], iyi bir atölye (dâr-us-sınaa) [...], iyi bir rejisör [...] ve sonra dekor, elbise ve sanatkâr. Beyefendi hazretleri; müsaadenizle söyliyelim ki yukarıda saydığımız şeylerin kaffesi bizde yoktur. (...) Yunanistan ve Bulgaristan, mütehassıslar sayesinde güzel şeritler yaparken bizim hiç bilmediğimiz, anlamadığımız bu sanatı yapayalnız yaşatacağımızı iddia etmek pek vâhidir. ${ }^{17}$

\footnotetext{
7 Alim Şerif Onaran, “Türk Sinemasına Otuz Yıl Emek Vermiş, Bu Alanda da Yapıtlarıyla Öncü Olmuştu”, Milliyet Sanat 324 (1979): 22.

8 Alim Şerif Onaran, Muhsin Ertuğrul’un Sineması, (Ankara: Kültür Bakanlığı Yayınları, 1981), 123.

9 Onaran, Muhsin Ertuğrul'un Sineması, 123.

10 Alim Şerif Onaran, Türk Sineması, (İstanbul: Kitle Yayıncılık, 1994), 21.

11 Burcu Yasemin Şeyben, "Muhsin Ertuğrul'un Sinemacilı̆̆’", Sinemada Bir Asır: Türk Sinemasının 100. Yılına Armağan, Ed. Abdurrahman Çelik, (Ankara: Hazırlık ve Tasarım Orient Basın Yayın, 2014), 31.

12 Sevinçli, "Muhsin Ertuğrul'un", 13.

13 Muhsin Ertuğrul, Benden Sonra Tufan Olmasın, (İstanbul: Remzi Kitabevi, 2007), 296.

14 Ertuğrul, Benden Sonra, 296.

15 Şeyben, "Muhsin Ertuğrul'un Sinemacılı̆̆ı", 31.

16 Ertuğrul, Benden Sonra, 275.

17 Nijat Özön, Türk Sinema Tarihi, 57-58.
} 
Ertuğrul, Almanya'daki film çalışmalarının ardından İstanbul'a döner. Kemal Film ile irtibat kurar. O güne dek film ithalatçılığı yapan Kemal Film’in yerli film işine girmesi ile birlikte Türk sinemasında yeni bir dönem başlar.

\section{Muhsin Ertuğrul'un Kemal Film Macerası}

Muhsin Ertuğrul Almanya'dan İstanbul'a dönüşünde iyi bir sinemacı olmak için azimlidir: "Sinema sanatında başarı ve üstünlüğün nedenlerini bulabilmek için böyle her kapıyı dolaşacağım. Kendimi cerre çıkmış çömezlere benzetiyorum." ${ }^{18}$ Alim Şerif Onaran, film yapımına Türkiye'de devam etme niyetinde olan Ertuğrul'un Bozkurt adını vermeyi düşündüğü bir stüdyo kurmak istediğini; ancak şartların pek müsait olmadığını dile getirir. ${ }^{19}$

Ayşegül Çelik, Ölmeyi Bilen Adam adlı çalışmasında film yapımına başlamak için teklifin Seden kardeşlerden geldiğini belirtir. ${ }^{20}$ Nitekim "Viyana'da bulunduğum 1922 yılında, Kemal ve Şakir Seden kardeşlerden İstanbul’a gelerek birlikte çalışmak üzere çağrı aldım”21 diyen Muhsin Ertuğrul dönemin koşullarını şu sözlerle anlatır:

Önerilerini kabul edip Türkiye’ye döndüğüm zaman İstanbul'da ne film y1kayacak bir laboratuar, ne bir stüdyo, ne bir film çekme makinesi, ne de bir basma makinesi, tek sözcükle teknik araç adına hiçbir şey bulunmamaktaydı. Teknik işlerle uğraşan üç kişi vardı: Fuat Uzkınay, Cezmi Ar ve laboratuarcı Hüseyin Bey. ${ }^{22}$

Nijat Özön ise Seden'leri film yapmak için Muhsin Ertuğrul'un ikna ettiğini ileri sürer:

Ertuğrul, henüz Almanya’daki sinema çalışmalarından gereken dersi çıkarmış görünmüyordu. Bundan başka, o zaman İstanbul'daki tiyatro hayatının düzensizliği, Almanya'daki sinema çalışmalarından sıcağı sıcağına dönen Ertuğrul'u ister istemez bu kolay ve zahmetsiz kazanç alanına itiyordu. Bundan dolayıdır ki, 1918 yılında, İstanbul'da sinema çalışmalarını imkânsız kılan şartlar olarak "Müdafaa-i Milliye Cemiyeti”ne sayıp döktükleri, 1922 yılında da sürüp gittiği halde, o vakit sinema işletmeciliğinin büyük bir bölümünü ellerinde tutan Seden'leri film yapımına geçmeğe kandırdı. ${ }^{23}$

Teklif kimden gelirse gelsin Muhsin Ertuğrul'un Kemal Film için gerçekleştirdiği ilk filmin maceralı yapım süreci aslında ne kadar zor bir işe kalkıştığını gösterir. Ertuğrul; oyuncu, teknik ekip, laboratuvar ve malzeme açısından yokluklar içinde bir sinema var etmeye çalışır:

Laboratuvar bulunmadığı için, Ali Efendi Sineması'nın abdesthanesini laboratuar olarak kullanmak üzere marangozlara ilkel küvetler ve çerçeveler ssmar-

18 Ayşegül Çelik, Ölmeyi Bilen Adam, (İstanbul: Can Yayınları, 2013), 137.

19 Onaran, “Türk Sinemasına”, 22.

20 Çelik, Ölmeyi Bilen Adam, 97.

21 Ertuğrul, Benden Sonra, 296.

22 Ertuğrul, Benden Sonra, 296.

23 Özön, Türk Sinema Tarihi, 72. 
ladık. Çatı arasındaki bir küçük bölmeye kopya makinesi koyarak, baskı ve montaj odası yaptık. ${ }^{24}$

Muhsin Ertuğrul; Kemal ve Şakir Seden kardeşlerin Kemal Film şirketi adına iki film çeker: Dönemin basınını günlerce meşgul eden bir cinayet olayından yola çıkılarak senaryolaştırılan ve büyük ilgi gören İstanbul'da Bir Facia-i Aşk (Şişli Güzeli Mediha Hanım'n Facia-i Katli) (1922) ve Yakup Kadri'nin Nur Baba isimli romanından uyarlanan Boğaziçi Esrarı (1922).

Muhsin Ertuğrul, Kemal Film adına çevirdiği ilk film olan İstanbul'da Bir Facia-i Aşk'ın çekimleri sırasında deneme çekimi yapmadan işe giriştiklerini ve ortaya çıkacak görüntülerin kalitesini merakla beklediklerini anlatır:

İlk gün, 120 metrelik film çekilmişti. Hüseyin Bey negatifleri banyo ederken Cezmi Ar, Muhsin Ertuğrul ve Seden kardeşler kapının önünde bekleşiyorlardı. Az sonra kapı açıldı, Hüseyin Beyin suratı allak bulaktı, "Haber kötü," dedi. Negatifler fazla ışıklandırıldığı için tamamen yanmıştı. [....]. Muhsin, Almanyadaki rejisörlük günlerinde, ışığı kovalarken karanlık negatifleri açma yöntemleri hakkında çok şey öğrenmişti. [....]. "Madem hepsi yanmış, bir denesek ne çıkar?” deyince adamcağız yeniden laboratuvara kapandı. Epey sonra kapıdan çıktığında hem şaşkın hem sevinçliydi; yöntem işe yaramış, negatifler kurtulmuştu. ${ }^{25}$

Nijat Özön, Muhsin Ertuğrul'un Kemal Film için çektiği ikinci film için de gişe gelirini garanti edecek sansasyonel bir konuya el attığını ifade eder. ${ }^{26}$ Ertuğrul, Yakup Kadri’nin Nur Baba romanını filme almaya karar verir. Roman, tekkesini güzel kadınları tuzağa düşürmek için kullanan istismarcı bir Bektaşi Şeyhi’nin hikâyesini anlatmaktadır. Ne var ki filmin Eyüp’teki çekimleri olaylı başlar. Romanın filme alındığını duyan Bektaşiler seti basarlar. Filmin Ermeni asıllı başrol oyuncusu canını zor kurtarır ve bir daha da filmde oynamayı reddeder. Onun rolünü Muhsin Ertuğrul üstlenir. Filmin çekimi polis gözetiminde tamamlanır ve gösterimi ancak İstanbul'un kurtuluşu sonrasında Boğaziçi Esrarı adıyla gerçekleşir. ${ }^{27}$

Muhsin Ertuğrul, 1923 yılında birbiri ardına üç film çeker. İlki Halide Edip’ten uyarladığ Ateşten Gömlek'tir. Ertuğrul, henüz sinema kariyerinin başındayken Cumhuriyet ideallerinin tiyatro ve sinema alanındaki temsilcisi misyonunu üstlenir. "Cumhuriyetin ilanına o güne dek çevrilmiş en iyi öykülü film olan 'Ateşten Gömlek'le girilir. 29 Ekim'den yaklaşık altı ay önce, işgalci güçlerin henüz terk etmediği İstanbul'da 'Ateşten Gömlek'in gösterimi olağanüstü canlı, coşkulu bir ortamın doğmasına yol açacaktır." 28

24 Ertuğrul, Benden Sonra, 296-297. 
Ateşten Gömlek, Kurtuluş Savaşı'nı konu alan ilk filmdir. Alim Şerif Onaran, filmin Muhsin Ertuğrul'un bu dönemdeki en önemli eseri olduğunu dile getirir:

Kurtuluş Savaşı'na katılan subaylarla onları destekleyen kadın kahramanların yiğitçe çabalarını ve aşklarını veren bu kurdelada Ertuğrul Muhsin, Bedia Muvahhit, Neyyire Neyyir, Emin Beliğ önemli roller üstlenmişlerdi. Bu film Kurtuluş Savaşı'ndan yeni çıkmış bir ulusun duygularını canlandırmakta son derece başarılı olmuş; gerek oyuncuların özverileri, gerekse çekim ve kurgu teknikleri bakımından öteki iki filmden üstün bir düzeyde görülmüşsü. ${ }^{29}$

Nijat Özön de Ateşten Gömlek filmine Ertuğrul'un filmografisi içinde ayrı bir yer verir. Özön'e göre bütün ilkelliğine rağmen Ateşten Gömlek filmi Kurtuluş Savaşı’nın ruhunu yansıtan bir filmdir. Ayrıca, müslüman kadınların ilk kez kamera önüne geçtikleri film olma özelliğini de taşımaktadır. ${ }^{30}$

Tanzimat, I. Meşrutiyet ve II. Meşrutiyet dönemlerindeki reformlara rağmen yeni kurulan Türkiye Cumhuriyeti, Osmanlı İmparatorluğu'ndan tutucu, yoksul, okuma yazması olmayan ve kadına sosyal hayatta yer tanımayan bir toplum yapısını miras almıştı. Bu anlamda, kadınların erkeklerle birlikte sahneye çıkması ve bir sinema filminde oynaması devrimci nitelikte olaylardır. Nitekim ünlü sinema tarihçisi Agâh Özgüç de dönemin koşullarını şu sözlerle anlatır:

Cumhuriyet öncesi Türkiye'sinde Müslüman Türk kadınlarının sahneye çıması, beyaz perdede görünmeleri yasaktı. Büyük bir çoğunluğa göre, film izlemenin bile "günah" sayıldığı dönemlerde kadın oyuncular ülkemize çeşitli nedenlerle yerleşmiş azınlıklardan seçiliyordu. Ama yine de tüm bu yasaklara karşı çıkıp, sanat uğruna savaş veren Türk kadınları vardı. Örneğin, 1920 yılında Saltanat Türkiye'sinin zaptiyeleri tarafından tutuklanıp karakola götürülen Afife Hanım, Jale takma adıyla Kadıköy'deki Apollon Tiyatrosu'nda sahneye çıkmış, bu nedenle de "umumi ahlaka uygun olmayan davranış" gerekçesiyle başı derde girmişti. ${ }^{31}$

Muhsin Ertuğrul, her ne kadar resmî tarih anlatılarında yer almasa da Cumhuriyet devrimlerinin gördüğ̈̈ muhalefetle mücadele etmek zorunda kalır. Ateşten Gömlek filmini çekerken karşılaştı̆̆ zorluklar bunun bir göstergesidir:

“Ateşten Gömlek", karşı karşıya geldiği olaylardan da anlaşılacağı gibi “çileli ve maceralı bir film"di. Bağnaz çevreler, Türk kadınları bu filmde oynadıkları için tepki göstermişlerdi. Özellikle de filmin dış sahnelerinin çekildiği bazı taşra yörelerinde taassup kol geziyordu. Anlatılanlara göre, film ekibine "fırınlar ekmek satmamış, bakkallar yüz gram teneke peynirini katık olarak çok görmüşler"di. Hatta bir çekim sırasında, köylüler toplanıp, muhtara başvurarak, çalışma yapılan yöreyi derhal terk etmeleri için baskı yapmışlardı. ${ }^{32}$

29 Onaran, “Türk Sinemasına”, 22-23.

30 Özön, Türk Sinema Tarihi, 78-79.

31 Özgüç, Başlangıcından Bugüne, 33.

32 Özgüç, Başlangıcından Bugüne, 37-38. 
Muhsin Ertuğrul, Ateşten Gömlek'ten sonra aynı yıl iki film daha çeker: Leblebici Horhor (1923) ve Kiz Kulesinde Bir Facia (1923). Leblebici Horhor filmi sahnede yakaladığı başarıyı perdede yakalayamaz. Nijat Özön, Kızkulesinde Bir Facia filmi ile Jean Grémillon'un aynı oyundan yola çıkarak beş yıl sonra çektiği Gardiens de Phare (1929) filmlerini karşılaştırır. ${ }^{33}$ Muhsin Ertuğrul'un yorumunu başarısız bulur. Grémillon'un uyarlamasında sinema dilinin çok daha iyi kullanıldığını dile getirir. ${ }^{34}$

Muhsin Ertuğrul, 1924 yılında tek filmle yetinir. Türk edebiyatının ünlü yazarlarından Peyami Safa’nın aynı adlı romanından uyarlanan Sözde Kızlar’’ çeker. Ertuğrul, Kemal Film döneminde kurmaca filmlerin yanı sıra belgesellere de imza atar. Nijat Özön, Kemal Film’in Muhsin Ertuğrul yönetiminde yaptığı belgesel filmlerin önemli tarihî dokümanlar olduğunu vurgular. ${ }^{35}$

Goskino $^{36}$ tarafından kendisine yönetmenlik teklif edilen Muhsin Ertuğrul, 1925 yılında Sovyetler Birliği’ne gider ve orada üç film çeker: Tamilla (1925), Spartakus (1926) ve 5 Dakika (1926). Alim Şerif Onaran, Ertuğrul'un Rusyada çektiği filmleri pek başarılı bulmaz. ${ }^{37}$ Buna rağmen Spartakus filminin kamera arkası fotoğraflarına dayanarak Ertuğrul'un Almanya'daki sinema çalışmalarını aşan bir çaba içinde olduğunu öne sürer. ${ }^{38}$ Baha Gelenbevi de bu konuda benzer görüşler dile getirir: "Ben Rusyada çevirdiği (İspartaküs) filminin bazı çalışma fotoğraflarını gördüm ve oradaki araç, gereç ve aksesuarın dağılışından o yapıtın, o dönemde revaçta bulunan İtalyan tarihi filmlerinden pek de aşağı olmadığı kanısını vermiştir.” ${ }^{39}$

Muhsin Ertuğrul'un kayıp olduğu düşünülen bu filmleri yıllar sonra SESAM Başkanı Yılmaz Atadeniz'in çabaları ve Rusya Devlet Arşivi’nde çalışanların yardımlarıyla bulunmuştur. Ne var ki filmleri elinde tutan şirket yöneticileri yüklü bir para talep etmiş ve resmi makamlara yapılan başvurular sonuçsuz kalmıştır. ${ }^{40}$

\section{Muhsin Ertuğrul'un İpekçiler Dönemi}

Rusya dönüşü Muhsin Ertuğrul'un sinemacılık macerası İpek Film için gerçekleştirdiği yapımlarla sürer. İpekçiler, aslında film ve fotoğraf malzemeleri ithalatçısıdır. 1920 yılında sinema işletmeciliğine başlayan İpekçiler, 1928 yılında İpek Film’i kurarak yapımcilığa soyunurlar ${ }^{41}$. Muhsin Ertuğrul, Türk sinemasının ikinci özel yapımevi olan İpek Film'le birçok ilke imza atar: İlk sesli film, ilk ortak yapım, ilk şarkılı film gibi ilkler Ertuğrul tarafından gerçekleştirilir. ${ }^{42}$

33 Özön, Türk Sinema Tarihi.

34 Özön, Türk Sinema Tarihi, 80-81.

35 Özön, Türk Sinema Tarihi, 81.

36 Sovyetler Birliği'nde sinemadan sorumlu en yüksek devlet organıdır.

37 Onaran, Muhsin Ertuğrul'un Sineması.

38 Onaran, Muhsin Ertuğrul'un Sineması, 131.

39 Baha Gelenbevi, "Muhsin Ertuğrul ve Sinema”, Ölümünün 5. Yılında Muhsin Ertuğrul Semineri Bildirileri, (İzmir: Ege Üniversitesi Atatürk Kültür Merkezi, 1984), 2.

40 Ali Rıza Özkan, "Muhsin Ertuğrul’un Kayıp Filmlerine Kim Sahip Çıkacak?”, 30 Nisan 2016, http://www. abcgazetesi.com/muhsin-ertugrulun-kayip-filmlerine-kim-sahip-cikacak-14683h.htm.

41 Gökhan Akçura, Doğumunun Yüzüncü Yılına Armă̆an: Muhsin Ertuğrul, (İstanbul: İstanbul Büyükşehir Belediyesi Kültür İşleri Dairesi Başkanlığı Yayınları, 1992), 15.

42 Çelik, Ölmeyi Bilen Adam, 143-144. 
Nijat Özön, Muhsin Ertuğrul'un Rusya’dan İstanbul'a sinema yapmak için değil, yeniden düzenlenen Darülbedayỉnin başına geçmek için döndügünü ileri sürer. ${ }^{43}$ Özöne göre, aslında Muhsin Ertuğrul sinemada pek bir şey yapamayacağını anlamış ve sinema ihtirası yüzünden tiyatrodaki geleceğini kaybetmek istememiştir.

Baha Gelenbevi, Muhsin Ertuğrul'un Rusya dönüşünde İpek Film’e "kapıland’”ğını öne sürer: "İpekçilerdeki bu 12 senelik dönemin ilk 10 senesi Muhsin Ertuğrul'un kati imparatorluk devresidir. Başka film çeviren müessese de bulunmadığından, İpek Filmin Türkiye piyasasında hegemoniyası hakimdir." ${ }^{34}$

Muhsin Ertuğrul, İpekçiler Dönemi'nin ilk filmi olan Ankara Postasinın yapımını 1929 'da bitirir. ${ }^{45}$ Ertuğrul'un Kemal Film döneminde sözünü ettiği olumsuz koşullar İpek Film döneminde de sürmektedir. Ankara Postası'nın başarısı Muhsin Ertuğrul'a yeni filmlerin kapısını açar.

Muhsin Ertuğrul, 1929 y1lında Kaçakçılar filminin çekimlerine başlar. Bu filmin çekimleri sürerken İpek Film Şirketi de İstanbul Nişantaşı’nda eski bir ekmek fabrikasını yeniden düzenleyerek ilk sesli film stüdyosuna dönüştürür. ${ }^{46}$ Oyuncuların geçirdiği trafik kazası nedeniyle Kaçakçılar filminin çekimleri ancak 1932 yılında tamamlanir. ${ }^{47}$

1930'lu yılların başında Beyoğlu sinemalarında ithal sesli filmlerin gösterimi başlar. Muhsin Ertuğrul da İstanbul Sokaklarında (1931) filmini sesli olarak çeker..$^{48} \mathrm{Bu}$ film aynı zamanda bir Türk, Mısır ve Yunan ortak yapımı olarak gerçekleştirilir. ${ }^{49}$ Semiha Berksoy, Talat Artamel, İsmail Galip Arcan gibi Türk oyuncuların yanı sıra Mısırlı Azize Emir ve Yunanlı Gavrilides’in başrollerini paylaştığı bu filmin seslendirme işlemleri Paris’teki Espinay stüdyolarında tamamlanır. ${ }^{50}$ İlk sesli Türk filmi ve ilk ortak yapım olarak kabul edilen İstanbul Sokaklarında filmi tantanalı bir tanıtımla 2 Aralık 1931 yılında Elhamra ve Melek sinemalarında gösterime girer. ${ }^{51}$

Muhsin Ertuğrul, 1930’lar Türkiyesindeki dönüşüme koşut işler gerçekleştirir. İpek Film döneminde farklı türlerde eserler verir ve Kurtuluş Savaşı̇nı yeniden ele alır. Alim Şerif Onaran, Ertuğrul'un Ateşten Gömlek (1923) ve Ankara Postası (1929) filmlerini çekmesine rağmen Kurtuluş Savaşı destanının sinemada henüz verilmediğine inandığını; bu nedenle de 1932 yılında Nizamettin Nazif'in hazırladığı bir sinopsisten yola çıarak Bir Millet Uyanıyor'un (1932) yapımını gerçekleştirdiğini ifade eder. ${ }^{52}$ Bir Millet Uyanıyor, sinema tarihçileri tarafından Muhsin Ertuğrul'un en önemli filmi kabul edilir:

43 Özön, Türk Sinema Tarihi.

44 Gelenbevi, "Muhsin Ertuğrul”, 3.

45 Onaran, Türk Sinemast, 26.

46 Nijat Özön, Karagözden Sinemaya Türk Sineması ve Sorunları, 1. Cilt, (İstanbul: Kitle Yayınları, 1995), 24.

47 Akçura, Muhsin Ertuğrul, 15.

48 Akçura, Muhsin Ertuğrul, 15.

49 Akçura, Muhsin Ertuğrul, 15.

50 Akçura, Muhsin Ertuğrul, 15.

51 Akçura, Muhsin Ertuğrul, 15.

52 Onaran, Türk Sinemast, 29. 
Bir Millet Uyanıyor, günün koşullarında Batı ölçülerine denk bir Milli Mücadele filmi. Bazı sahnelerde Ordu Film Merkezi’nin İstiklal Savaşı dokümanlarından yararlanılmış. O zamana değin yapılan filmlerde, büyük zorunluluklar olmadıkça, Darülbedayi oyuncularının dışında eleman pek kullanılmıyordu. Bu filmle birlikte tiyatro çevresinin dışındaki oyunculara da önemli roller verilmeye başlanıld1. ${ }^{53}$

Baha Gelenbevi, Muhsin Ertuğrul'un Bir Millet Uyanıyor adlı filmini bir başyapıt olarak değerlendirir; ancak İpek Film'in bir yapımcı olarak yaptığı baskıların Ertuğrul'un işlerinin kalitesini düşürdügünü savunur:

[P]rodüktörler zamanla filmciliği öğrendikleri hesabına kapılarak, rejisörü bir tür baskıya alarak, piyasanın gustosuna uygun filmler yapmağa zorlamaya başladılar. Prodüktör İpekçi kardeşlerin arasında tek başına kalan rejisör, hele senelerin ahbablığının münasebetlerin ciddiyetini aşındırması da hesaba katılınca, onun artık öz sanat yolunda direnebilmesinin ne kadar güç, hatta olanaksız olduğu kolay anlaşılacaktır. ${ }^{54}$

Nijat Özön, Bir Millet Uyanıyor filmine Muhsin Ertuğrul'un filmografisi içinde ayrı bir yer verse de bu filmde Ertuğrul'un devrimci Rus sinemasından yararlanmasının taklitçilik düzeyini geçmediğini ileri sürer. ${ }^{55}$ Özön, bu filmde, Ertuğrul'un sesli sinemaya geçildiği bir dönemde sessiz sinemanın trüklerini kullandığını ifade eder. ${ }^{56}$

Muhsin Ertuğrul'un 1932 yazında çekimine başladığı bir diğer film Karım Beni Aldatırsa'dır. Aynı yıl, sinemada sesli filmlerin yanı sıra şarkılı filmler de moda olmuştur. ${ }^{57} \mathrm{Bu}$ eğilim tiyatro temsillerinde etkili olmuş ve Şehir Tiyatrosu'nda Yalova Türküsü ile başlayan operet temsilleri büyük rağbet görmüştür. ${ }^{58}$ Gökhan Akçura, Muhsin Ertuğrul'un ciddi ve kaliteli yapımlara duyduğu eğilime rağmen daha geniş bir seyirci kitlesine ulaşabilmek için operetlerin devamına karar verdiğini öne sürer. ${ }^{59}$ Nitekim bu dönemde İpek Film de operet filmlerine ağırlık verilmesini istemiş ve Ertuğrul 1933 yılında Söz Bir Allah Bir ile Cici Berber filmlerini çekmiştir. ${ }^{60}$

Cici Berber adlı müzikli vodvilin senaryosunu Mümtaz Osman takma adıyla Nazım Hikmet yazmıştır. ${ }^{61}$ Muhsin Ertuğrul, bu dönemde Türkiye ve Yunanistan işbirliği ile yine çok uluslu ortak bir yapım olan Fena Yolu (O Kakos Dhromos) (1933) çeker. Ertuğrul'un filmografisi içinde Nazım Hikmet'in imzasını taşıyan senaryolardan biri de Milyon Avcıları (1934) olur. ${ }^{62}$

\footnotetext{
53 Fikret Hakan, Türk Sinema Tarihi, (İstanbul: İnk1lâp Kitabevi, 2012), 63.

54 Gelenbevi, "Muhsin Ertuğrul”, 3-4.

55 Özön, Türk Sinema Tarihi.

56 Özön, Türk Sinema Tarihi, 99.

57 Akçura, Muhsin Ertuğrul, 18.

58 Akçura, Muhsin Ertuğrul, 18.

59 Akçura, Muhsin Ertuğrul, 18.

60 Akçura, Muhsin Ertuğrul, 18.

61 Giovanni Scognamillo, Türk Sinema Tarihi, (İstanbul: Kabalcı Yayınevi, 1998), 60

62 Scognamillo, Türk Sinema Tarihi, 60.
} 
Ertuğrul'un 1923 yılında Kemal Film döneminde uyarladığı Dikran Çuhacıyan’ın Leblebici Horhor opereti, 1934 yılında İpek Film’in yapımcılığında bu kez sesli olarak çekilir. ${ }^{63}$ Gökhan Akçura, geçmişteki başarısızlığın tekrarlandığını ve gişe gelirinin maliyetin çok gerisinde kaldığını dile getirir. ${ }^{64}$ Buna rağmen Leblebici Horhor, Türk sinema tarihinde yurt dışından ödül kazanan ilk film olur. 2. Uluslararası Venedik Film Şenliği'ne katılan film onur diploması alır. ${ }^{65}$

Giovanni Scognamillo, Muhsin Ertuğrul'un 1930'lu yıllarda İpekçiler'in yapımcıl1ğında çektiği filmlerde ticari kaygıların ağır bastığını ve gişe garantisi için popüler konuların seçildiğini ifade eder. ${ }^{66}$ Ancak Ertuğrul, İpekçilerin mali krize girdikleri bir dönemde, ilk kez ticari baskı olmaksızın bağımsız olarak nitelendirilebilecek bir film yapar. ${ }^{67} 1934$ yılında Aysel, Bataklı Damın Kızı filmini çeker. Selma Lagerlöf'ün Bataklı Damın Kızı (Tösefran Starmyrtorpet) adlı hikâyesi Hasan Cemal Çambel tarafindan sinemaya uyarlanır. ${ }^{6}$

Baha Gelenbevi, Türk sinemasının ilk köy filmi olarak kabul edilen Aysel, Bataklı Damın Kızı filmi hakkında şu değerlendirmeyi yapar:

Burada köy yaşamı fazlaca mefkureleşmiş (idealize edilmiş) idi; fakat yine de şimdilerde moda olan "Anadolu realizmasından mesaj" getirdik diye, "sefalet şarkısı” söylemiyordu hiç olmazsa. Zaten Anadolu'da hiçbir zaman sefalet olmamıştır, sefalet sanılan şey "zaruret"tir. Sefalet pislik ve acizdir, zaruret ise kaderdir yalnızca. İşte Muhsin, bu kılpayı farkı idrak etmiştir. ${ }^{69}$

Nijat Özön ise Muhsin Ertuğrul'un Aysel, Bataklı Damın Kızı filmini görüntüleri bakımından Muhsin Ertuğrul-Cezmi Ar ikilisinin en başarılı filmi olarak değerlendirir. $^{70} \mathrm{Ne}$ var ki filmdeki köyün bir dekor olmaktan öteye geçemediğini ve filmin genel olarak köydeki sosyal gerçekliği yansıtmaktan uzak olduğunu ileri sürer. ${ }^{71}$ Giovanni Scognomillo'ya göre de Aysel, Bataklı Damın Kızı, sinema olmaya daha yakındır; ancak filmin oyunculuktan dekorlara kadar birçok kusuru vardır. ${ }^{72}$

Muhsin Ertuğrul'un İpekçiler dönemindeki tekeli Musahipzade Celâl'in oyunlarından uyarlanan Aynaroz Kadısı (1938) ile Bir Kavuk Devrildi (1939); Ziya Şakir Sado'nun eserinden uyarlanan Allahın Cenneti (1939), Jean de Letraz'in Bichon adlı oyunundan uyarlanan Tosun Paşa (1939) filmleri ile sona erer. ${ }^{73}$

63 Akçura, Muhsin Ertuğrul, 75.

64 Akçura, Muhsin Ertuğrul, 75.

65 Agâh Özgüç, 1000 Karede Türk Sineması, (İstanbul: Aksav Yayınları, 2006), 57.

66 Scognamillo, Türk Sinema Tarihi, 59-60.

67 Akçura, Muhsin Ertuğrul, 75; Onaran, Türk Sineması, 30; Şeyben, “Muhsin Ertuğrul'un Sinemacılığı”, 33.

68 Onaran, Türk Sinemast, 30.

69 Gelenbevi, "Muhsin Ertuğrul”, 4.

70 Özön, Türk Sinema Tarihi.

71 Özön, Türk Sinema Tarihi, 101-102.

72 Scognamillo, Türk Sinema Tarihi, 85.

73 Scognamillo, Türk Sinema Tarihi, 60. 


\section{Geçiş Döneminde Muhsin Ertuğrul}

1930’lu yılların sonunda tiyatro dışından gelen rakiplerle birlikte Muhsin Ertuğrul'un ve İpek Film'in sinemadaki tekeli kırılır. Nijat Özön'ün ifadesiyle Türk sinemasında "Geçiş Dönemi” (1939-1950) olarak adlandırılan yeni bir dönem başlar. ${ }^{74}$ Bu dönem, “Tiyatrocular ile Sinemacılar arasında da, bir çeşit köprü işlevi gören, bir ayağ 1 tiyatro bir ayağı sinemada olan sinemacıların yer aldığ [bir dönemdir]". ${ }^{75}$

Faruk Kenç (1910-2000), Geçiş Dönemi’ni başlatan yönetmen olarak kabul edilir. 1939 yılında asıl işi plak dolduruculuğu ve film ithalatı olan Halil Kamil tarafından Türk Film Stüdyosu kurulur ve sonradan Ha-Ka Film adını alır. ${ }^{76}$ Almanyada fotoğrafçılık eğitimi alan Faruk Kenç, Türkiye’ye döndüğünde Ha-Ka Film’e yönetmen olarak girer ve ilk filmi Taş Parçası (1939)'nı çeker.

Reşat Nuri Güntekin'in eserinden uyarlanan Taş Parçası, Muhsin Ertuğrul tekelinin dışına çıkan ilk deneme olarak kabul edilir. ${ }^{77}$ Dönemin sinema yazarlarından biri olan Burhan Arpad, Mimar Sinan Sinema Televizyon Merkezi tarafından hazırlanan Türk Sinema Tarihi (1986) adlı belgeselde, bu film için “Ertuğrul'un başına düşen taş" ifadesini kullanır. ${ }^{78}$

Faruk Kenç ise kendisiyle yapılan bir söyleşide Muhsin Ertuğrul'un kurduğu tekelin gücünü Taş Parçası filminin çekimlerinde yaşadığı bir olayla örneklendirir:

Taş Parçası filmini çekiyoruz, bitirmek üzereyiz. Bir günlük iş kaldı. Fakat Suavi ile Nevzat Okçugil’i çağırıyoruz gelmiyorlar. Muhsin Bey’e mektup yazdık; böyle böyle diye. Ertesi gün hemen geldiler. Muhsin Bey zılgıt geçmiş. Kalkıp geldiler ve filmi bitirdik. Orada kandırıyorlar. Gitmeyin, filme devam etmeyin, etmezseniz Muhsin Bey’in gözüne girerseniz, Muhsin Bey size hem filmde, hem tiyatroda rol verir diye. ${ }^{79}$

Taş Parçası'ndan sonra Yılmaz Ali (1940), Kıvırıık Paşa (1941) ve Dertli Pınar (1942) filmlerini çeken Faruk Kenç'in açtığı bu yolda Baha Gelenbevi, Şadan Kamil, Şakir Sırmalı, Turgut Demirağ ve Çetin Karamanbey gibi yeni yönetmenler de ortaya çıkar. ${ }^{80} \mathrm{Bu}$ yönetmenler arasında yurtdışında fotoğrafçılık ya da sinemacılık eğitimi almış okullu sinemacıların yanı sıra sinema eğitimi almamış olanlar da vardır; ancak hepsinin ortak özelliği tiyatro çevresinden olmamalarıdır.

Engin Ayça’ya göre, Geçiş Dönemi'nde Muhsin Ertuğrul'un yönetmenlik tekeli kırılmış; ama bu dönemde film çekenler aynı estetik kalıplarla aynı seyirci kitlesine

74 Özön, Karagözden Sinemaya, 25.

75 Özön, Karagözden Sinemaya, 18.

76 Özön, Türk Sinema Tarihi, 118-119.

77 Okan Ormanlı, “Türk Sinemasında Geçiş Dönemi ve Toplumsal Altyapısı (1939-1950)” (Yüksek lisans tezi, 2006), 20.

78 Ormanl1, “Türk Sinemasında”, 46.

79 Ormanlı, "Türk Sinemasında”, 47.

80 Özön, Türk Sinema Tarihi. 
film yapmışlardır. ${ }^{81}$ Artık Türk sinemasının tek yönetmeni vasfını kaybetmiş olan Muhsin Ertuğrul, film çalışmalarını Geçiş Dönemi’nde de sürdürür ve birkaç iddialı girişimde bulunur. Ertuğrul, 1940 yılında Şehvet Kurbanı filmini çeker. Baha Gelenbevi, Cahide Sonku’nun Aysel, Bataklı Damın Kizı'ndan sonra oynadığı Sehvet Kurbaninı "prodüktörlerden paçasını kurtarmış" bir film olarak nitelendirir. ${ }^{82}$ $\mathrm{Bu}$ dönemde kendini aşmaya çalışan Muhsin Ertuğrul, özellikle Cahide Sonku’nun çekim gücünden yararlanır. Ertuğrul, Aysel, Bataklı Damın Kızı, Şehvet Kurbanı ve Kıskanmak filmlerinde başrol verdiği Cahide Sonku ile Türk sinemasına ilk büyük kadın yıldızını kazandırır.

Sabiha Sertel, Muhsin Ertuğrul'un Şehvet Kurbanı filmini gayet başarılı bulur ve Ertuğrul'un Türk sinemasını da tıpkı tiyatroda olduğu gibi daha ileri taşıyacağını düşünür:

[E]serin filme çekilişinde bazı küçük kusurlarına rağmen fevkalâde muvaffakiyet vardır. Şimdiye kadar çekilen filmler tiyatronun ilk Türkiye hudutlarına girdiği gün geçirdiği iptidailik gibi bir devre geçirdikten sonra bu eserde çok ileri bir tekâmüle mazhar olmuştur. Ertuğrul Muhsin, Türk Tiyatrosu’nu uzun mücadelelerden sonra nasıl Avrupa ayarında bir tiyatro haline getirmiş ise, bu eserle de sinemayı böyle bir tekâmüle kavuşturacağını müjdeliyor. ${ }^{83}$

Giovanni Scognomillo ise Şehvet Kurbaninı genel olarak başarılı bulmaz. Hikâyenin klişelerden oluştuğunu ve filmin bir oyunculuk gösterisi gibi çekildiğini söyler ${ }^{84} \mathrm{Ge}-$ riden gösterim (back projection) tekniğinin uygulandığı tren sahnesini ise ayrı bir yere koyar. ${ }^{85}$

Muhsin Ertuğrul’un İpekçiler dönemindeki son filmi Kahveci Güzeli (1941) olur. Bu film, Baha Gelenbevi tarafından içerikten yoksun ancak görüntü nizamı açısından temiz bir film olarak değerlendirilir. ${ }^{86}$ Muhsin Ertuğrul, 1945'te senaryosu Necdet Mahfi Ayral'a ait olan Yayla Kartali'nı ve 1946'da Harman Sonu'nu çeker. Gelenbevi'ye göre, Ertuğrul 1947 yılında başarılı bir pastoral film yapar: Kızılırmak-Karakoyun. ${ }^{87}$ Lütfi Akad, filmin Nâzım Hikmet'e ait olan senaryosunun sansüre Ercüment Er takma adı ile gönderildiği bilgisini verir. ${ }^{88}$

Muhsin Ertuğrul, 1953 yılında son bir hamle yapar. Yapı Kredi Bankası'nın desteğiyle ilk renkli film olarak kabul edilen Halıcı Kız (1953)'ı çeker. Burcu Yasemin Şeyben'e göre, Hahıcı Kız projesinin Ertuğrul'a emanet edilmesi ve bankanın açtığı kredi onun isminin piyasada hâlâ geçerli olduğunu göstermektedir. ${ }^{89}$

81 Engin Ayça, "Yeşilçam Halkın, Ulusun, Genelin Bizzat Kendisiydi”, Sinema Söyleşileri 2004, Haz. Ferhat Koray Sağlam, (İstanbul: Boğaziçi Üniversitesi Yayınevi, 2015), 86.

82 Gelenbevi, "Muhsin Ertuğrul”, 4.

83 Scognamillo, Türk Sinema Tarihi, 87-88.

84 Scognamillo, Türk Sinema Tarihi.

85 Scognamillo, Türk Sinema Tarihi, 89.

86 Gelenbevi, "Muhsin Ertuğrul”, 4.

87 Gelenbevi, "Muhsin Ertuğrul”, 4.

88 Ö. Lütfi Akad, Işıkla Karanlık Arasında, (İstanbul: Türkiye İş Bankası Kültür Yayınları), 447.

89 Şeyben, "Muhsin Ertuğrul'un Sinemacilığı”, 35. 
Halıcı Kız filminin ilk olarak Vedat Nedim Tör'e ait bir senaryoya göre ve Şehir Tiyatrosu oyuncularıyla gerçekleştirilmesi planlanmıştır. ${ }^{90}$ Daha sonra ise Mebrure Sami Alevok'un hazırladığı bir senaryodan yola çıkılarak Isparta'da geçen bir olaya dönüştürülmüş; çoğunlukla Küçük Sahne ve Devlet Tiyatrosu oyuncuları ile birlikte hayata geçirilmiştir. ${ }^{91} \mathrm{Ne}$ var ki film, teatrel özellikleri ve Heyecan Başaran’n halıcı kız rolüne uygun olmayışı nedeniyle gişede büyük bir hayal kırıklığı yaratmıştır.92 Baha Gelenbevi, Muhsin Ertuğrul'un bu filmdeki başarısızlığının, Türkiye'de renkli filmin yaygınlaşmasını en az on yıl geciktirdiğini ileri sürer. ${ }^{93}$ Fikret Hakan’a göre, Ertuğrul bu filmde umduğunu bulamayınca sinemayı bırakır. ${ }^{94}$

\section{Muhsin Ertuğrul'un Mirası}

Muhsin Ertuğrul, çektiği filmlerle birçok ilke imza atar ve Türk sinemasının genetik kodlarını oluşturur. Ne var ki birçok olumsuzluğun vebali de onun omuzlarına yüklenir. Muhsin Ertuğrul hakkındaki literatürde daha çok Nijat Özön’ün yazdıkları egemendir. Özön, oldukça sert bir üslûpla Muhsin Ertuğrul'u "sinema diktatörlügüu" ile itham eder ve onun sinemadaki on yedi yılını "boşa giden yıllar" olarak nitelendirir. ${ }^{95}$ Üstelik Özön'e göre "bu on yedi yll büsbütün boş geçseydi daha iyi olurdu; zira üç filmin kazandırdıkları yanında geri kalanların getirdiği kötü alışkanlıklar çok daha ağır basıyordu." 96

Nijat Özön'ün Muhsin Ertuğrul hakkında yaptığı bazı değerlendirmelerin haksız olduğu söylenebilir. Özön, Muhsin Ertuğrul'un Müdafaa-i Milliye Cemiyeti’ne 16 Ocak 1919 yllında yazdığı mektupta ifade ettiği olumsuz koşullar aradan üç sene geçmesine rağmen hâlâ değişmediği hâlde film çekmeye girişmesini bir tutarsılılık olarak görür. ${ }^{97}$

Nijat Özön’e göre, Muhsin Ertuğrul'un Almanyada rejisörlük yaptığı filmler dördüncü, beşinci sınıf bir şirketin yapımcıllğında gerçekleştirilmiştir. ${ }^{98} \mathrm{Bu}$ filmlerin senaryolarına kaynaklık eden eserler de "çırpıştırma işi”" serüven romanlarıdır. ${ }^{99}$ Özön'ün Ertuğrul'un Almanya'daki çalışmaları hakkındaki eleştirilerinin satır aralarında alaycı bir tavır gizlidir. Özön, Ertuğrul'un yaptıkları ile söylediklerinin aslında çeliştiğini ima eder.

Nijat Özön, Muhsin Ertuğrul'un Rusya’da yaptığı çalışmaları da kayda değer bulmaz. Özöne göre, Muhsin Ertuğrul ne Almanyaddaki ne de Rusya'daki sinema deneyimlerinden gerektiği kadar yararlanabilmiştir. Almanya'da Ekspresyonizm’in, Sovyet Rusyada ise Devrim Sineması'nın revaçta olduğu dönemde bu ülkelerde film çekmiş olmasına rağmen bu iki önemli sinema anlayışının filmleri üzerindeki etkisi çok sı-

90 Onaran, Türk Sineması, 38.

91 Onaran, Türk Sineması, 38.

92 Onaran, Türk Sineması, 38.

93 Gelenbevi, "Muhsin Ertuğrul”, 4.

94 Hakan, Türk Sinema Tarihi, 43.

95 Özön, Türk Sinema Tarihi, 109.

96 Özön, Türk Sinema Tarihi, 109.

97 Özön, Türk Sinema Tarihi, 72-73.

98 Özön, Türk Sinema Tarihi, 63.

99 Özön, Türk Sinema Tarihi, 64. 
nırlı düzeyde kalmıştır. ${ }^{100}$ Nitekim Özön, Ertuğrul’un Rusya'da yaptığı filmlerin sinema tarihçilerinin de ilgisini çekmediğini dile getirir. ${ }^{101}$

Nijat Özön'ün Muhsin Ertuğrul hakkındaki bu sert eleştirileri zamanla Türk sinema tarihi literatüründe kalıcılaşmıştır. Necip Tosun, Özön’ün bu konudaki belirleyici etkisine dikkat çeker:

Ulaşamadığı film hakkında görüş bildirmek zorunda olan yazarlar, kaçınılmaz olarak yazılı kaynaklara, özellikle Nijat Özön'ün yaklaşımlarına teslim olmak zorunda kalmışlardır. Sinema eleştirmenleri bu dönemlerle ilgili yazılarında Nijat Özön'ün yaklaşımlarının aksine neredeyse tek satır yazamamışlar, bu yazarın genellemelerine tam bir uyum içerisinde değerlendirmeler yapmışlardir. ${ }^{102}$

Özön'ün eleştirilerinden yola çıkan eleştirmen, akademisyen ve sinema tarihçileri, Ertuğrul'u Türk sinemasındaki olumsuzlukların başlıca sorumlusu olarak görmüşlerdir.

Haldun Dormen, Türk tiyatrosunun Muhsin Ertuğrul'a çok şey borçlu olduğunu vurgular; ancak Ertuğrul'u "dünyanın en kötü yönetmenlerinden biri” olarak nitelendirir. ${ }^{103}$ Baha Gelenbevi ise Muhsin Ertuğrul'un sinemada bir “diktatörya” kurduğunu ve kendisinden sonra gelecek bir "hayrülhalef" yetiştirmediğini iddia eder. ${ }^{104}$ Oğuz Makal'a göre, Ertuğrul on yedi yıl boyunca Türk sinemasında tekel kurmuştur. ${ }^{105}$ Muhsin Ertuğrul, Behçet Güleryüz'ün ifadesiyle "Tek Parti döneminin tek sinemac1sı" olmuştur. CHP’nin siyaset yapma tekelini elinde tutmasına benzer şekilde, Ertuğrul da film yapma tekelini elinde tutmuştur:

İlginç bir tesadüftür ki CHP’nin Tek Parti iktidarını içine alan zaman dilimi neredeyse Muhsin Ertuğrul'un Türk sinemasının tek egemeni olduğu yıllara denk gelmektedir. Bu dönemselleştirme yalnızca Türk sinema geleneğinden kaynaklanan bir kopuş olmamakla birlikte Türkiye'nin aynı zamanda sosyo-ekonomik değişiminin kırılma noktasını da göstermektedir. ${ }^{106}$

Beşir Ayvazoğlu da Muhsin Ertuğrul'u tek parti iktidarının tiyatro ve sinemadaki temsilcisi olarak görür. Cumhuriyetçi aydınların tepeden inmeci yaklaşımları ve halka yüksekten bakmaları gibi bilindik tutumların Muhsin Ertuğrul'da da bulunduğunu söyler. ${ }^{107}$ Ayvazoğlu’na göre, Ertuğrul tiyatro ve sinemada bir tür diktatörlük kurmuş ve yerli dil arayışlarının önünü kesmiştir. ${ }^{108}$ Nitekim Giovanni Scognomillo’nun

100 Özön, Türk Sinema Tarihi.

101 Özön, Türk Sinema Tarihi, 84.

102 Necip Tosun, “Karagözden Sinemaya’ ya da Kırk Yil Sinemaya Çarpık Bakmak”, Dergâh 67 (1995): 22.

103 Haldun Dormen, “Bence İnsan Bir Şey Olmak İstiyorsa, Olmak Zorunda”, Sinema Söyleşileri 2006, (İstanbul: Boğaziçi Üniversitesi Yayınevi, 2007), 320.

104 Gelenbevi, "Muhsin Ertuğrul”, 5.

105 Makal, "Muhsin Ertuğrul”, 2.

106 Behçet Güleryüz, "Muhsin Ertuğrul’un Köy Filmleri ve Cumhuriyet Aydınının İkilemi”, Taşrada Var Bir

Zaman, Ed. Z. Tül Akbal Süalp ve Aslı Güneş, (İstanbul: Çitlembik Yayınları, 2010), 211-212.

107 Beşir Ayvazoğlu, Geleneğin Direnişi, (İstanbul: Ötüken Neşriyat, 1996), 67.

108 Ayvazoğlu, Geleneğin Direnişi, 67. 
Muhsin Ertuğrul’a yönelttiği temel eleştiri yerli kaynaklardan çok Batılı kaynakları kullanmış olmasıdır: "[S]ineması konusunda bizce en önemli eksikliği, aşırı şekilde Batı'ya açık olması, Batı kalıplarına bağlılık göstermesi ve Türk sinemasına, sonraki yıllarda bir salgın haline gelecek olan uyarlama yöntemini aşılamasıdır." ${ }^{109}$

Yerli kaynaklardan çok yabancı kaynaklardan beslenen Muhsin Ertuğrul, özgün bir sinema dili de geliştirememiştir. Nitekim Türkiye'de sanatın diğer alanlarında olduğu gibi sinema alanında da bir gecikmişlik durumu söz konusudur. Muhsin Ertuğrul, Batı Avrupa'daki sinemacıların teatrel etkilerden kurtulup sinema dilini keşfettikleri bir dönemde ilk filmlerini çekmeye başlar. Mahmut Tali Öngören, yurt dışında sinema çalışmaları yapan Muhsin Ertuğrul'un Türkiye’ye döndükten sonra bir sinema dili ortaya koymasının beklendiğine dikkat çeker. ${ }^{110}$ Ancak yine de Türk sinemasının ilk dönemlerindeki tiyatro etkisini göz önünde bulundurarak Muhsin Ertuğrul Sineması'nı anlaşılır nedenlerle teatrel bir sinema olarak nitelendirir. ${ }^{111}$ Sinemacılar döneminin ünlü yönetmenlerinden Memduh Ün de Muhsin Ertuğrul'un filmlerinin sinema dilinin kullanımı açısından kusurlu olduğunu dile getirir. ${ }^{12}$ Ün’e göre bunun nedeni Türkiye'de sinema tekniğinin o yıllarda henüz yeni olmasıdır. ${ }^{113}$

Giovanni Scognomillo, Muhsin Ertuğrul Sineması'nın teatrel bir sinema olduğu konusunda Nijat Özön ile hemfikirdir:

Bunca yıl sinema diye bir "perde" kurmuştur, ama bir "beyazperde" değil, sadece hareket halinde olan bir "tiyatro perdesi” olmuştur bu. Belki Ertuğrul daha fazlasını istemiyordu. Son söz yine Ertuğrul'undur: "Zaman sınırı ve para kazanma hırsı olmadan bir film çevirmeyi ben de isterdim, ama olmadı işte!"114

Oğuz Makal'a göre, Muhsin Ertuğrul'un tiyatro uyarlamalarını sinemaya taşımasının ardında ekonomik zorunluluklar vardır. ${ }^{115}$ Makal, tek bir stüdyo ile bir iki filmin üretildiği cılız yapıda tiyatroya yönelimi doğal karşılamaktadır. Nitekim Makal, yapım giderleri karşılanamadığı için yarım kalan Leblebici Horhor filminin ancak oyunculardan Behzat Budak’ın bulduğu kredi sayesinde tamamlanabildiğini söyler. ${ }^{116}$

Behçet Güleryüz, Muhsin Ertuğrul'un tiyatroyu yüksek bir sanat biçimi olarak gördüğünü, sinemanın onun için ikinci planda kaldığını ifade eder. ${ }^{17}$ Güleryüz’e göre, Ertuğrul'un anılarının büyük bir kısmını tiyatroya ayırmış olması bu durumun bir

109 Scognamillo, Türk Sinema Tarihi, 61.

110 Mahmut Tali Öngören, “Türk Sinemasının Sorunları”, Ölümünün 5. Yılında Muhsin Ertuğrul Semineri Bildirileri, (İzmir: Ege Üniversitesi Atatürk Kültür Merkezi, 1984).

111 Öngören, “Türk Sinemasının Sorunları”, 2.

112 Memduh Ün, "Yapımcılı̆̆ım, Yönetmenliğimi Törpüledi”, Sinema Söyleşileri 2004, (İstanbul: Boğaziçi Üniversitesi Yayınevi, 2006), 5.

113 Ün, "Yapımcılığım”, 5.

114 Scognamillo, Türk Sinema Tarihi, 94.

115 Makal, "Muhsin Ertuğrul”.

116 Makal, "Muhsin Ertuğrul", 3.

117 Güleryüz, “Muhsin Ertuğrul'un”. 
göstergesidir. ${ }^{118}$ Güleryüz, Cumhuriyeti yönetenlerin dahi Muhsin Ertuğrul'u sinema konusunda yeterli görmediklerini dile getirir:

Cumhuriyet'in 10. yıl belgeselinin Rus yönetmenlere yaptırılması ya da Cumhuriyet için çekilecek propaganda filmleri için Batı ülkeleri sinemacılarıyla anlaşılmaya çalışılması yönetici elitlerin de görüşlerinin bu doğrultuda olduğunun açık bir göstergesidir. ${ }^{119}$

Beşir Ayvazoğlu, tiyatrocu kimliğinden kopamayan Muhsin Ertuğrul'un Türk sinemasına çeyrek asır kaybettirdiğini iddia eder. ${ }^{120}$ Ayvazoğlu, Muhsin Ertuğrul Sineması'na karşı asıl tepkinin Yeşilçam Sineması'ndan geldiğini ileri süren Halit Refiğ in görüşlerini paylaşır:

Tek parti devrinin karakterini çizen Muhsin Ertuğrul sinemasına karşıllı, Demokrat Parti'nin iktidara geliş yıllarında başlayan Yeşilçam sineması, aynı yıllarda tıpkı siyasetin halka açılışı gibi, sinemanın halka açılışı ve ulusal özellikler taşımaya başlaması bakımından sinema tarihimizde ileri ve olumlu bir adımdır. ${ }^{121}$

Alim Şerif Onaran, Ertuğrul'u adeta bir günah keçisi olarak gören Nijat Özön ve onun çizgisindeki eleştirmenlere göre daha gerçekçi değerlendirmeler yapar. Onaran, Muhsin Ertuğrul'un kötü uygulamaları olduğunu kabul etmekle birlikte önayak olduğu ilkler ve sinemaya disiplinli bir çalışma temposu getirmesi nedeniyle hak ettiği yeri alması gerektiğini vurgular. ${ }^{122}$ Ertuğrul'un sinema alanındaki başarısızlıkları kadar başarılarına da dikkat çeken Onaran bazı eleştirileri "insafsızlık" olarak nitelendirir: "Ertuğrul'u kendi dönemi içinde değerlendirmek ve yapmadıklarıyla değil, yaptıklarını göz önünde tutarak değerlendirmek doğru olacaktır."123

Alim Şerif Onaran, birtakım aralıklarla da olsa kırk yılı aşkın bir süre sinemada emek veren Muhsin Ertuğrul'un sadece sinemacı kimliğine değil, bir kültür ve sanat adamı olma özelliğine de dikkat çeker. ${ }^{124}$ Tıpkı Cumhuriyet’i kuran kadro gibi Muhsin Ertuğrul da kültür sahasındaki deneyimsizliğine ve sözü edilen olumsuz koşullara rağmen bir tür öncü rolü üstlenir. Sinemayı var edebilmek için inisiyatif alır. Başkalarının bir şey yapılamaz dediği ve belki de bunun için suçlanamayacağı bir ortamda işe girişir. Eğitmenlik, yönetmenlik, eleştirmenlik, oyunculuk ve çevirmenlik gibi birçok misyonu aynı anda üstlenmek zorunda kalır. Ertuğrul'un yalnızca sinemayla uğraşmak gibi bir lüksü olmamıştır. Bu durum, aslında dönemin ruhu (zeitgeist) ile ilgilidir.

Muhsin Ertuğrul'un filmleri, resmi ideolojinin ve Kemalist modernleşme projesinin sinemadaki izdüşümüdür. Ertuğrul bu anlamda rejimle tam bir mutabakat hâlindedir. Engin Ayça da Muhsin Ertuğrul'un Kemalist aydınlanma projesi içindeki rolüne

118 Güleryüz, "Muhsin Ertuğrul'un”, 220.

119 Güleryüz, "Muhsin Ertuğrul'un”, 220-221.

120 Ayvazoğlu, Geleneğin Direnişi, 67-68.

121 Ayvazoğlu, Geleneğin Direnişi, 68.

122 Onaran, "Türk Sinemasına", 23.

123 Onaran, Türk Sinemast, 39.

124 Onaran “Türk Sinemasına”, 22. 
dikkat çeker. ${ }^{125}$ Yeni kurulan Cumhuriyet'te Ertuğrul'un sanat alanında Batılılaşma misyonunu üstlendiğini dile getirir. Ayça, Ertuğrul'un filmlerinin senede 100 yabanc1 filmin gösterime girdiği ve elektriğin bulunduğu birkaç büyük şehirde gösterildiğini ifade eder. ${ }^{126}$ Aslında Ertuğrul, o zamanın Türkiye’sindeki sinema ortamını etkileyecek bir potansiyele sahip değildir. Ancak sinema alanında hiçbir alt yapının olmamasındansa kusurlu da olsa bir başlangıç yapılmış olması oldukça önemlidir.

İmparatorluk bakiyesinden bir ulus devlet yaratmak hiç de kolay değildir. Cumhuriyet, kadınların kamusal alana girmesini sağlamış, onlara seçme ve seçilme hakkı vermiştir. Ertuğrul'sa, Türk kadınını sahneye çıkarmış ve Cumhuriyet'in getirdiği Batılı ideallerin sanat alanındaki temsilcisi olmuştur. Bu anlamda Muhsin Ertuğrul, filmlerinde Türk kadınını tıpkı modernleşme projesinin elitleri gibi bir sembol olarak görmüştür. Peki Muhsin Ertuğrul Kemalist devrimleri bu kadar hararetle desteklerken ülkenin yönetici elitleri Muhsin Ertuğrul'u neden yeterince desteklememişlerdir? Aslında Kemalist rejim, özellikle köylerde yürütmek istediği toplumsal mühendislik projesi için sinemanın etkin gücünün farkındadır; ama imkânsızlıklar yüzünden sinemayı kullanamamıştır. Nitekim Kurtuluş Savaşı sonrasında Türkiye adeta bir yangın yerine dönmüştür. Uzun süredir devam eden savaşlarda yüz binlerce insan ölmüş ya da sakat kalmıştır. Kara, demir ve deniz yolu ulaşımı dönemin standartlarının çok gerisindedir. Elektrik şebekesi yalnızca İstanbul, İzmir ve Tarsus gibi birkaç büyük yerleşim yeri ile sınırlıdır. En temel ihtiyaç maddeleri bile ithal edilmektedir. Dolayısıyla sinema, o dönemin Türkiye'sinde kırsal nüfusa ulaşmayı sağlayacak bir araç değildir. Bu yüzden Kemalist elitler sinema işini İpekçiler’e ve Muhsin Ertuğrul'a bırakmışlardır.

\section{Sonuç}

Muhsin Ertuğrul, tüm hayatı boyunca gündelik heyecanlarının peşine takılan bir heveskâr değil, hedeflerine ulaşmak için her türlü zorluğu göze alan bir idealist olmuştur. Ertuğrul, oyun seyretme terbiyesinden oyuncu yetiştirmeye kadar her alanı kapsayan bir tiyatro kültürünü kurumsallaştırmaya çalışmıştır. Kırk yıla yakın bir süre tiyatro çalışmalarının yanı sıra sinema çalışmalarını da sürdürmüştür.

Başta Nijat Özön olmak üzere birçok sinema tarihçisinin de ifade ettiği gibi, Muhsin Ertuğrul'un tiyatroculuğu sinemacılığına ağır basmaktadır. Ertuğrul, gerek kendi kişisel sınırlılıkları gerekse ülkenin içinde bulunduğu koşullar nedeniyle ancak birkaç filminde vasatın üzerine çıkabilmiştir. Çektiği onlarca film içinde Ateşten Gömlek (1923), Bir Millet Uyanıyor (1932) ve Aysel, Bataklı Damın Kızı (1934) filmlerinde belli bir estetik düzeyi yakaladığı söylenebilir.

Alim Şerif Onaran’ın çalışmaları, Muhsin Ertuğrul hakkındaki önyargılı değerlendirmelerin etkisini bir ölçüde azaltmıştır. Ne var ki yokluklar içinde mücadele etmenin zorlukları ve öncü olmanın sıkıntıları, Ertuğrul'un bir günah keçisi olarak görülmesini engelleyememiştir. Cumhuriyet'in ilk yıllarındaki olumsuz koşullar göz önünde bulundurulduğunda her aşamada teknolojiye bağlı bir sanatı icra etmek ce-

125 Ayça, "Yeşilçam".

126 Ayça, "Yeşilçam", 78. 
saret gerektirir. Bu açıdan, ortaya koyduğu eserlerin tüm kusurlarına rağmen Muhsin Ertuğrul'un sinemanın Türkiyede varolabilmesi için harcadığı çaba yok sayılamaz. Ertuğrul'un sinema mirası birçok yönden eleştirilebilirse de yerli filmcilik kavramı onunla birlikte konuşulur hâle gelmiş, bir yerli film izleyicisi oluşmuş ve sinemacılık meslek olarak kabul edilmiştir.

Muhsin Ertuğrul, yalnızca bir tiyatrocu ve sinemacı değildir. Aynı zamanda Cumhuriyet'in ideallerinin hayata geçirilmesi için mücadele etmiş bir kültür adamıdır. Ertuğrul, bir ölüm kalım savaşı sonrasında kendi dilini ve kültürünü inşa etmeye çalışan, ciddi ekonomik ve sosyal problemleri olan genç bir ülkede tiyatro ve sinema sanatının temellerini atmıştır.

\section{Kaynakça}

Akad, Ö. Lütfi. Işılkla Karanlık Arasında. İstanbul: Türkiye İş Bankası Kültür Yayınları, 2004.

Akçura, Gökhan. Doğumunun Yüzüncü Yılına Armağan: Muhsin Ertuğrul. İstanbul: İstanbul Büyükşehir Belediyesi Kültür İşleri Dairesi Başkanlığı Yayınları, 1992.

Ayça, Engin. "Yeşilçam Halkın, Ulusun, Genelin Bizzat Kendisiydi”. Sinema Söyleşileri 2014. Haz. Ferhat Koray Sağlam. İstanbul: Boğaziçi Üniversitesi Yayınevi, 2015. 70-104.

Ayvazoğlu, Beşir. Geleneğin Direnişi. İstanbul: Ötüken Neşriyat, 1996.

Çelik, Ayşegül. Ölmeyi Bilen Adam. İstanbul: Can Yayınları, 2013.

Dormen, Haldun. "Bence İnsan Bir Şey Olmak İstiyorsa, Olmak Zorunda”. Sinema Söyleşileri 2006. İstanbul: Boğaziçi Üniversitesi Yayınevi, 2007. 318-340.

Ertuğrul, Muhsin. Benden Sonra Tufan Olmasın. İstanbul: Remzi Kitabevi, 2007.

Ertuğrul, Muhsin. Insan ve Tiyatro Üzerine “Gördüklerim”. İstanbul: Yankı Yayınları, 1975.

Gelenbevi, Baha. “Muhsin Ertuğrul ve Sinema”. Ölümünün 5. Yılında Muhsin Ertuğrul Semineri Bildirileri. İzmir: Ege Üniversitesi Atatürk Kültür Merkezi, 1984.

Güleryüz, Behçet. "Muhsin Ertuğrul’un Köy Filmleri ve Cumhuriyet Aydınının İkilemi”. Taşrada Var Bir Zaman. Ed. Z. Tül Akbal Süalp ve Aslı Güneş. İstanbul: Çitlembik Yayınları, 2010. 211-234.

Hakan, Fikret. Türk Sinema Tarihi. İstanbul: İnk1lâp Kitabevi, 2012.

Makal, Oğuz. “Muhsin Ertuğrul Sineması Üzerine Bir Değerlendirme”. Ölümünün 5. Yılında Muhsin Ertuğrul Semineri Bildirileri. İzmir: Ege Üniversitesi Atatürk Kültür Merkezi, 1984.

Onaran, Alim Şerif. Muhsin Ertuğrul'un Sineması. Ankara: Kültür Bakanlığı Yayınları, 1981.

Onaran, Alim Şerif. Türk Sineması. İstanbul: Kitle Yayıncılık, 1994.

Onaran, Alim Şerif. “Türk Sinemasına Otuz Yıl Emek Vermiş, Bu Alanda da Yapıtlarıyla Öncü Olmuştu”. Milliyet Sanat 324 (1979): 22-25. 
Öngören, Mahmut Tali. “Türk Sinemasının Sorunları”. Ölümünün 5. Yılında Muhsin Ertuğrul Semineri Bildirileri. İzmir: Ege Üniversitesi Atatürk Kültür Merkezi, 1984.

Ormanlı, Okan. “Türk Sinemasında Geçiş Dönemi ve Toplumsal Altyapısı (19391950)". Yüksek lisans tezi, Marmara Üniversitesi, 2006.

Özgüç, Agâh. Başlangıcından Bugüne Türk Sinemasında İlkler. İstanbul: Yılmaz Yayınları, 1990.

Özgüç, Agâh. 1000 Karede Türk Sineması. İstanbul: Aksav Yayınları, 2006.

Özkan, Ali Rıza. “Muhsin Ertuğrul'un Kayıp Filmlerine Kim Sahip Çıkacak?”. 30 Nisan 2016. http://www.abcgazetesi.com/muhsin-ertugrulun-kayip-filmlerinekim-sahip-cikacak-14683h.htm.

Özön, Nijat. Karagözden Sinemaya Türk Sineması ve Sorunları. 1. Cilt. İstanbul: Kitle Yayınları, 1995.

Özön, Nijat. Türk Sinema Tarihi: Dünden Bugüne 1896-1960. İstanbul: Artist Reklam Ortaklığı Yayınları, 1962.

Scognamillo, Giovanni. Türk Sinema Tarihi. İstanbul: Kabalcı Yayınevi, 1998.

Sevinçli, Efdal. "Muhsin Ertuğrul'un Tiyatro ve Sinema Yazıları”. Ölümünün 5. Yılında Muhsin Ertuğrul Semineri Bildirileri. İzmir: Ege Üniversitesi Atatürk Kültür Merkezi, 1984.

Şeyben, Burcu Yasemin. "Muhsin Ertuğrul'un Sinemacılı̆̆ı”. Sinemada Bir Asır: Türk Sinemasının 100. Yılına Armağan. Ed. Abdurrahman Çelik. Ankara: Hazırlık ve Tasarım Orient Basın Yayın, 2014.

Tosun, Necip. “'Karagözden Sinemaya’ ya da Kırk Yıl Sinemaya Çarpık Bakmak”. Dergâh 67 (1995).

Ün, Memduh. "Yapımcılığım, Yönetmenliğimi Törpüledi.” Sinema Söyleşileri 2004. İstanbul: Boğaziçi Üniversitesi Yayınevi, 2006. 3-28. 
İNSAN\&İNSAN, Yıl/Year 3, Say1/Issue 10, Güz/Fall 2016, 64-83

e-ISSN: 2148-7537, www.insanveinsan.org

\title{
Muhsin Ertuğrul: The Founder or the Scapegoat of Turkish Cinema?
}

SEÇKIN SEVIM

\begin{abstract}
Muhsin Ertuğrul (1892-1979) shaped the genetic codes of Turkish cinema with his films he shot in the early decades of the Rebuplic. The literature about Ertuğrul is dominated by Nijat Özön's critics. Critics that are influenced by Özön's arguments, held Ertuğrul responsible for the negativities of Turkish cinema. Alim Şerif Onaran's studies reduced the effect of biased critics about Ertuğrul to some extent. However, the difficulties of struggling in a severe poverty and being a precursor did not prevent Ertuğrul from being considered as a scapegoat. Muhsin Ertuğrul's theatrical identity supersedes his filmmaker identity as many historians of cinema stated before. Ertuğrul managed to go beyond average only in a few of his films. Even if his cinema heritage can be criticised in many ways, his effort for founding of Turkish cinema cannot be underestimated. Muhsin Ertuğrul has an exceptional place in the history of Turkish cinema because in severe poverty he managed to establish the cinema, which is the most technological branch of arts. Muhsin Ertuğrul's films can be watched as a reflection of the Kemalist modernisation project. Ertuğrul was a man of culture who struggled to realize the revolutions of the Republic with self-devotion. He was not only the man who made the Turkish women appear in the silver screen but also he became a representative of the ideals of the Rebuplic in field of art during all his life. For this purpose, he was obliged to undertake many missions such as teaching, directing, criticising, acting and translating at the same time. He laid the foundations of theatre and cinema in a country where fighting against epidemic diseases and educating its population at least in a level of primary school were only priorities. Thus, the aim of this study is to put forward the founder role of Muhsin Ertuğrul in Turkish cinema.
\end{abstract}

Keywords: Turkish cinema, Muhsin Ertuğrul, The Republic, The role of founder. 